\title{
Crystal structure and microwave dielectric properties of $\mathrm{Ca}\left[\left(\mathrm{Li}_{1 / 3} \mathrm{Nb}_{2 / 3}\right)_{0.92} \mathrm{Zr}_{0.08}\right]_{\mathrm{O}_{3-\delta}-\mathrm{xTiO}}$ ceramics
}

\author{
Wen Guo ${ }^{1, a}$, Gang Xiong 1, b \\ Department of Electronic and Information Engineering, Hubei University of Science and Technology, Xianning 437100, China.
}

\begin{abstract}
The effects of $\mathrm{B}_{2} \mathrm{O}_{3}$ on the sinterability and microwave dielectric properties of $\mathrm{Ca}\left[\left(\mathrm{Li}_{1 / 3} \mathrm{Nb}_{2 / 3}\right)_{0.92} \mathrm{Zr}_{0.08}\right] \mathrm{O}_{3-\delta}$ ceramics were investigated. $\mathrm{B}_{2} \mathrm{O}_{3}$ doping can effectively reduce sintering temperatue by $150 \sim 200^{\circ} \mathrm{C}$. The temperature coefficient of resonator frequency $\tau \mathrm{f}$ increased with an increase of $\mathrm{B}_{2} \mathrm{O}_{3}$ content and sintering temperatue. When $\mathrm{B}_{2} \mathrm{O}_{3}$ of $2 \mathrm{wt} \%$ were added, the optimum microwave dielectric properties: $\varepsilon_{\mathrm{r}}=28.5$, Qf $=13560 \mathrm{GHz}$ and $\tau_{\mathrm{f}}=-7.6 \times 10-6 /{ }^{\circ} \mathrm{C}$ were obtained at the sintering temperature of $950^{\circ} \mathrm{C}$.
\end{abstract}

\section{Introduction}

Recently multiplayer microwave filters were widely focused and developed in microwave circuits to meet the rapid development of advanced telecommunication. Microwave dielectric ceramics to be employed in multiplayer devices require low sintering temperature to cofired with the inner low less conductors and low melting point electrode such as $\mathrm{Cu}$ and $\mathrm{Ag}$. Among those low-temperature-cofired ceramics(LTCC) $\mathrm{Ca}\left(\mathrm{Li}_{1 / 3} \mathrm{Nb}_{2 / 3}\right) \mathrm{O}_{3-\delta}$ ceramics have been newly developed and widely investigated because of its excellent microwave dielectric properties and low sintering temperature of about $1150{ }^{\circ} \mathrm{C}[1,2]$. For the applications of LTCC, the complex perovskite should be further adjust to lower its sintering temperature. In our preliminary work, we found the $\mathrm{Ca}\left[\left(\mathrm{Li}_{1 / 3} \mathrm{Nb}_{2 / 3}\right)_{0.92} \mathrm{Zr}_{0.08}\right] \mathrm{O}_{3-\delta}$ ceramics having the superior dielectric properties: $\varepsilon_{\mathrm{r}}=28.6, \mathrm{Qf}=23880 \mathrm{GHz}$ and $\tau_{\mathrm{f}}=-$ $14.9 \times 10^{-6} /{ }^{\circ} \mathrm{C}$ after sintering at $1170^{\circ} \mathrm{C}$ for 4 h. P.Liu et al. $[3,4]$ have reported the addition of $\mathrm{B}_{2} \mathrm{O}_{3}$ were effectively in reducing the firing temperature of $\mathrm{Ca}\left(\mathrm{Li}_{1 / 3} \mathrm{Nb}_{2 / 3}\right) \mathrm{O}_{3-\delta^{-}}$ based ceramics. So in this paper we employed $\mathrm{B}_{2} \mathrm{O}_{3}$ additive as a sintering flux to decrease the sintering temperature of the ceramics. The microwave dielectric properties was also investigated with the discussion of its relationships with the phase formation in the present system.her.

\section{Experimental}

The $\mathrm{Ca}\left[\left(\mathrm{Li}_{1 / 3} \mathrm{Nb}_{2 / 3}\right)_{0.92} \mathrm{Zr}_{0.08}\right] \mathrm{O}_{3-\delta}$ powder compositions were synthesized by the conventional solid-state reaction method. High purity ( $\geq 99.9 \%$ ) oxide powders of $\mathrm{CaCO}_{3}$, $\mathrm{Li}_{2} \mathrm{CO}_{3}, \mathrm{Zr} \mathrm{O}, \mathrm{Nb}_{2} \mathrm{O}_{5}, \mathrm{TiO}_{2}$, were weighed according to the desired stoichiometry, and ground in an agate pot with distilled water for $4 \mathrm{~h}$ in a planetary mill. The prepared powders calcined at $900^{\circ} \mathrm{C}$ for $2 \mathrm{~h}$ in a closed
$\mathrm{Al}_{2} \mathrm{O}_{3}$ crucible. The calcined powders were milled for $3 \mathrm{~h}$ again with addition of $\mathrm{B}_{2} \mathrm{O}_{3}$, and then pressed into disks under a pressure of $150 \mathrm{Mpa}$. The disks were palced in a closed $\mathrm{Al}_{2} \mathrm{O}_{3}$ crucible to prevent the volatility of $\mathrm{Li}$ and sintered from $930^{\circ} \mathrm{C}$ to $1100^{\circ} \mathrm{C}$ for $4 \mathrm{~h}$ in air. The bulk densities of sintered specimens were measured by Archimedes method. Phase formation and microstructure were examined by X-ray diffractometer (X'Pert PRO) using $\mathrm{CuK} \alpha$ radiaiton. The measurement of microwave dielectric properties were performed on $\mathrm{TE}_{011}$ mode at the resonant frequency from 4 to $7 \mathrm{GHz}$ by the HakkiColeman's dielectric resonator method using a network analyer (ADVANTEST R3767C). The temperature coefficient of resonator frequency $\left(\tau_{\mathrm{f}}\right)$ was calculated at the range between $20^{\circ} \mathrm{C}$ and $80^{\circ} \mathrm{C}$

\section{Results and Discussion}

Fig. 1 show X-ray diffraction patterns of $\mathrm{Ca}\left[\left(\mathrm{Li}_{1 / 3} \mathrm{Nb}_{2 / 3}\right)_{0.92} \mathrm{Zr}_{0.08}\right] \mathrm{O}_{3-\delta}$ with $\mathrm{B}_{2} \mathrm{O}_{3}$ specimens sintered at $950^{\circ} \mathrm{C}$ for $4 \mathrm{~h}$. The diffraction peaks can be indexed according to the $\mathrm{CaTiO}_{3}$-type orthorhombic perovskite structure. Pure $\mathrm{Ca}\left[\left(\mathrm{Li}_{1 / 3} \mathrm{Nb}_{2 / 3}\right)_{0.92} \mathrm{Zr}_{0.08}\right] \mathrm{O}_{3-\delta}$ specimens sintered at $1170^{\circ} \mathrm{C}$ for $4 \mathrm{~h}$ was single phase. With $\mathrm{B}_{2} \mathrm{O}_{3}$ content increases, the peaks of superlattice diffractions of specimen 1:2 decreases until disappear, the degree of B-site 1:2 ordering will decrease, second phase appearence.Figure 1. Caption of the Figure 1. Below the figure. 


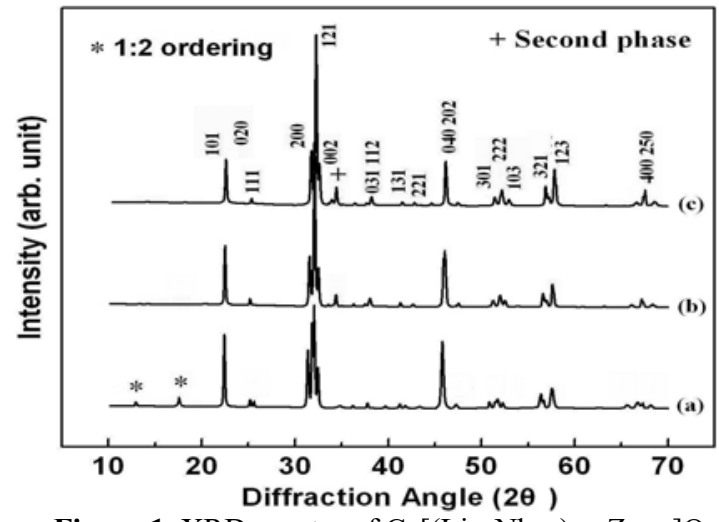

Figure 1. XRD spectra of $\mathrm{Ca}\left[\left(\mathrm{Li}_{1 / 3} \mathrm{Nb}_{2 / 3}\right)_{0.92} \mathrm{Zr}_{0.08}\right] \mathrm{O}_{3-\delta}$ specimens sintered at $950^{\circ} \mathrm{C}$ for $4 \mathrm{~h}$ with content of $\mathrm{B}_{2} \mathrm{O}_{3}$.

Fig. 2 shows the relationship between the dielectric constant and the $\mathrm{B}_{2} \mathrm{O}_{3}$ content in $\mathrm{Ca}\left[\left(\mathrm{Li}_{1 / 3} \mathrm{Nb}_{2 / 3}\right)_{0.92} \mathrm{Zr}_{0.08}\right] \mathrm{O}_{3-\delta}$ sintered at $950^{\circ} \mathrm{C}$ for $4 \mathrm{~h}$. The $\varepsilon r$ value increased with increasing $\mathrm{B}_{2} \mathrm{O}_{3}$ content from 0.5 to $1.5 \mathrm{wt} \%$, which could be contributed to the increased apparent density. However, as $\mathrm{B}_{2} \mathrm{O}_{3}$ content became greater than $1.5 \mathrm{wt} \%$, Er began to decrease because of the increasing of the secondary phase as confirmed in Fig. 1..

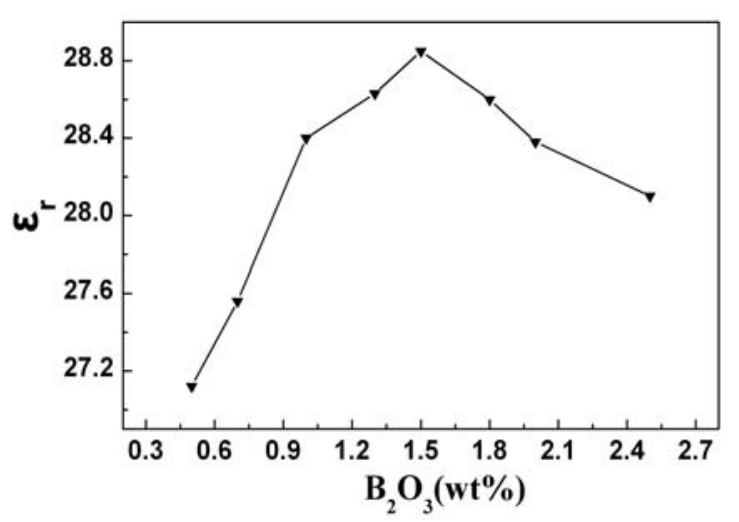

Figure 2. $\varepsilon_{\mathrm{r}}$ values of $\mathrm{Ca}\left[\left(\mathrm{Li}_{1 / 3} \mathrm{Nb}_{2 / 3}\right)_{0.92} \mathrm{Zr}_{0.08}\right] \mathrm{O}_{3-\delta}$ specimens sintered at $950^{\circ} \mathrm{C}$ for $4 \mathrm{~h}$ with content of $\mathrm{B}_{2} \mathrm{O}_{3}$.

Fig. 3 shows the Qf value of $\mathrm{Ca}\left[\left(\mathrm{Li}_{1 / 3} \mathrm{Nb}_{2 / 3}\right)_{0.92} \mathrm{Zr}_{0.08}\right] \mathrm{O}_{3-\delta}$ specimens with $\mathrm{B}_{2} \mathrm{O}_{3}$ sintered at $950^{\circ} \mathrm{C}$ for $4 \mathrm{~h}$. The addition of $\mathrm{B}_{2} \mathrm{O}_{3}$ greatly reduced the $Q f$ value of $\mathrm{Ca}\left[\left(\mathrm{Li}_{1 / 3} \mathrm{Nb}_{2 / 3}\right)_{0.92} \mathrm{Zr}_{0.08}\right] \mathrm{O}_{3-\delta}$ specimens. This is expected since $\mathrm{B}_{2} \mathrm{O}_{3}$ addition inhibited the degree of $1: 2$ ordering in $\mathrm{Ca}\left[\left(\mathrm{Li}_{1 / 3} \mathrm{Nb}_{2 / 3}\right)_{0.92} \mathrm{Zr}_{0.08}\right] \mathrm{O}_{3-\delta}$ ceramics and thus cause the decreases of the quality factor[5,6]. As increasing $\mathrm{B}_{2} \mathrm{O}_{3}$ content, the $\mathrm{Ca}\left[\left(\mathrm{Li}_{1 / 3} \mathrm{Nb}_{2 / 3}\right)_{0.92} \mathrm{Zr}_{0.08}\right] \mathrm{O}_{3-\delta}$ specimens were dense graducally, and the Qf values of specimens firstly increased and then decreased. The reason for this is the appearance of the second phase in the specimen as mentioned above. It was reported that the Qf value relates to relative density and second phase[7].

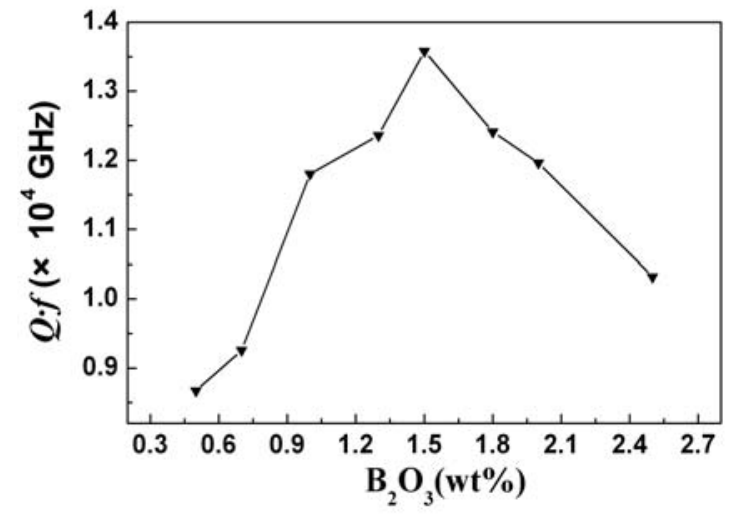

Figure 3. Qf values of $\mathrm{Ca}\left[\left(\mathrm{Li}_{1 / 3} \mathrm{Nb}_{2 / 3}\right)_{0.92} \mathrm{Zr}_{0.08}\right] \mathrm{O}_{3-\delta}$ specimens sintered at $950^{\circ} \mathrm{C}$ for $4 \mathrm{~h}$ with content of $\mathrm{B}_{2} \mathrm{O}_{3}$.

Fig. 4 shows temperature coefficient of resonant frequency of $\mathrm{Ca}\left[\left(\mathrm{Li}_{1 / 3} \mathrm{Nb}_{2 / 3}\right)_{0.92} \mathrm{Zr}_{0.08}\right] \mathrm{O}_{3-\delta}$ with $\mathrm{B}_{2} \mathrm{O}_{3}$ specimens sintered at $950^{\circ} \mathrm{C}$ temperatures. The $\tau_{\mathrm{f}}$ value ranged from negative value of $-13.8 \mathrm{ppm} /{ }^{\circ} \mathrm{C}$ to negative value of $-7.8 \mathrm{ppm} /{ }^{\circ} \mathrm{C}$ when $\mathrm{B}_{2} \mathrm{O}_{3}$ content increased from 0.5 to $1.5 \mathrm{wt} \%$,and then decreased. By doping $1.5 \mathrm{wt} \%$ $\mathrm{B}_{2} \mathrm{O}_{3}$, the $\mathrm{Ca}\left[\left(\mathrm{Li}_{1 / 3} \mathrm{Nb}_{2 / 3}\right)_{0.92} \mathrm{Zr}_{0.08}\right] \mathrm{O}_{3-\delta}$ ceramics show the optimized microwave dielectric properties: $\varepsilon_{\mathrm{r}}=28.4$, Qf $=13560 \mathrm{GHz}$ and $\tau_{\mathrm{f}}=-7.8 \times 10^{-6} /{ }^{\circ} \mathrm{C}$ after sintering at $950^{\circ} \mathrm{C}$, indicating that the sintering temperatue of $\mathrm{Ca}\left[\left(\mathrm{Li}_{1 / 3} \mathrm{Nb}_{2 / 3}\right)_{0.92} \mathrm{Zr}_{0.08}\right] \mathrm{O}_{3-\delta}$ could be reduced to $950^{\circ} \mathrm{C}$ without degraduation of dielectric properties.

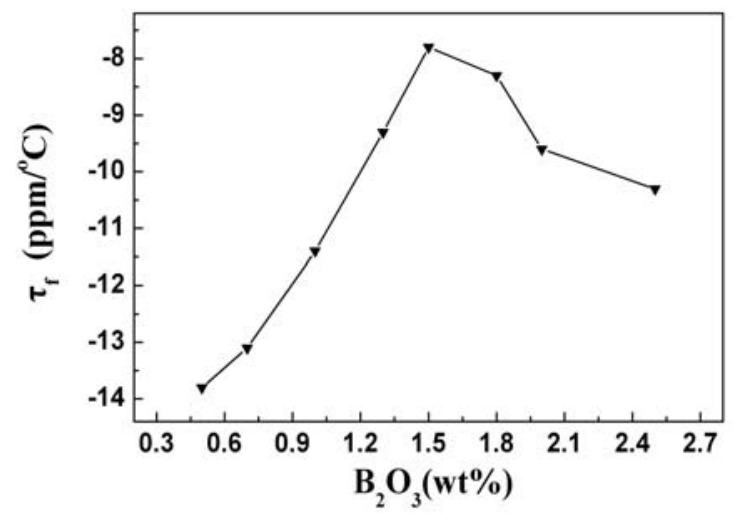

Figure 4. $\mathrm{T} f$ values of $\mathrm{Ca}\left[\left(\mathrm{Li}_{1 / 3} \mathrm{Nb}_{2 / 3}\right)_{0.92} \mathrm{Zr}_{0.08}\right] \mathrm{O}_{3-\delta}$ specimens sintered at $950^{\circ} \mathrm{C}$ for $4 \mathrm{~h}$ with content of $\mathrm{B}_{2} \mathrm{O}_{3}$.

\section{Summary}

Doping of $\mathrm{B}_{2} \mathrm{O}_{3}$ improves the microwave dielectric properties of $\mathrm{Ca}\left[\left(\mathrm{Li}_{1 / 3} \mathrm{Nb}_{2 / 3}\right)_{0.92} \mathrm{Zr}_{0.08}\right] \mathrm{O}_{3-\delta}$ ceramics sintered at $950{ }^{\circ} \mathrm{C}$.As increasing $\mathrm{B}_{2} \mathrm{O}_{3}$ additive content, the $\varepsilon_{\mathrm{r}}$ and the Qf value firstly increased then decreased from 28.6.8 and $12410 \mathrm{GHz}$ to 2.5 and $10320 \mathrm{GHz}$, respectively with further doping content of $\mathrm{B}_{2} \mathrm{O}_{3}$ from $1.8 \mathrm{wt} \%$ to $2.5 \mathrm{wt} \%$. The $\tau_{\mathrm{f}}$ value gradually moved to a positive direction with the increase of $\mathrm{B}_{2} \mathrm{O}_{3}$ content. When $\mathrm{B}_{2} \mathrm{O}_{3}$ of $1.5 \mathrm{wt} \%$ were added, the optimum microwave dielectric properties: $\varepsilon_{\mathrm{r}}=28.5, \mathrm{Qf}$ $=13560 \mathrm{GHz}$ and $\tau_{\mathrm{f}}=-7.6 \times 10^{-6} /{ }^{\circ} \mathrm{C}$ were obtained at the sintering temperature of $950^{\circ} \mathrm{C}$. 


\section{Acknowledgements}

This work was supported by the China Undergraduate Scientific and Technological Innovation Project (No.201610927004).

\section{References}

1. J.W. Choi, C.Y. Kang, S.J. Yoon, H.J. Kim and H.J. Jung, J. Mater. Res, 14 (1999)

2. J.W. Choi, J.Y. Ha, S.J. Yoon, H.J. Kim and K.H. Yoon, Jpn. J. Appl. Phys. 43 (2004)

3. P. Liu, E.S. Kim , K.H. Yoon: Jpn. J. Appl. Phys., 40 (2001)

4. P. Liu, E.S. Kim, S.G. Kang, Mater. Chem. Phys. , 79(2003).

5. I.T. Kim, Y.H. Kim, S.J. Chung, Jpn. J. Appl. Phys., 34(1995).

6. P.K. Davies, J. Tong, T. Negas, J. Am. Ceram. Soc., 80(1997)

7. D.M. Iddles, A.J. Bell, A.J. Moulson, J. Mater. Sci., 27(1992). 